\title{
INDONESIAN FOLKTALES IN ENGLISH: MEDIA TO INTEGRATE LOCAL WISDOM IN EFL CLASSROOM
}

\author{
Muhammad Fadhli \\ Universitas Bengkulu \\ mfadhli@unib.ac.id
}

\begin{abstract}
Indonesia has a lot of folktales as one of the precious cultural heritages that must be preserved. A folktale provides cultural knowledge and moral lessons as one type of literary text. Using Indonesian folktales in English as teaching materials in the classroom of English as a Foreign Language (EFL) will contribute a great deal to the growth of the linguistic and cognitive skills, cultural understanding and moral values of students. This paper focuses on some of the benefits and considerations of using Indonesian traditional folktales in English as a teaching aid in the EFL classroom.
\end{abstract}

Keywords: Folktales; EFL classroom; Culture knowledge

\section{INTRODUCTION}

Indonesian traditional folktales are one of the most important cultural heritages. Indonesian folktales must be taught to students in order to save the folktales from extinction. As one form of literary text, traditional folktales are precious because they represent a country's national cultural identity. Anderson (1991) states that national cultural identity is a major element of a nation's life. In line with this, in order to prevent extinction as a result of globalization and commercial entertainment, Cigay (2010) notes that folktales, myths and legends need to be preserved in this digital era.

One way to introduce traditional folktales to learners is to use them in English subjects as teaching materials. English teachers can incorporate cultural knowledge and moral values as well as some language elements through Indonesian folktales in English as learning material in the EFL classroom. Folktale exists in the form of stories that offer meaningful cultural identity of message and material (Harun \& Jamaludin, 2013). Accordingly, Fuhler, Farris and Hatch (1998) note that folktales can help students grasp the reality of human diversity and increase their empathy for people from other cultures. In addition, as cited in Prastiwi (2013), Citraningtyas (2012) states that local material, particularly in the form of folktales could promote the development of national identity and enhance the awareness of national culture for students. In line with this, Prasetyo (2016) stated that it is not only beneficial to maintain the cultural heritage to provide folklore, but also beneficial to help EFL students study English, help them gain cultural acquisition, and give them positive values to their character building.

Some scholars have carried out studies on the teaching of English using folktales. Alim (2011) found that folktale has dual roles as a linguistic setting that provides a cultural context for the language used and the social environment. Prastiwi (2013) found that in the teaching of English as a foreign language, the use of local cultural material serves two purposes: to encourage mastery of the target language (L2) while also allowing teachers to fulfil their duty to teach local culture. Additionally, Ismail (2019) found that the use of folklore stories offers genuine reading resources that give students the opportunity to emotionally intermingle with the text and involve themselves personally. Besides, several studies have been carried out on several aspects of folktales such as cultural-historical aspects (Cubitt, 2006; Dundes, 2007; Gottschall et al., 2004), philological-literary aspects (Babalola \& Onanug a, 2012; Hamilton, 2012; Lwin, 2010) sociological and psychological aspects (Haase, 1993; Ragan, 2009; Westland, 1993).

Based on the description above, this paper would specifically highlight some of advantages and considerations of using folktales as instructional materials in the classroom for English as a foreign language (EFL).

\section{MATERIALS AND METHOD}

\subsection{Folktales and Cultural Knowledge}

Every country has its own folktales that represent its country's beliefs, customs, rituals, or values. Folktales derive from the oral storytelling practices of the respective communities of groups of people, are known as fiction, typically timeless and placeless, usually tell the exploits of animal or human 
characters, and contain traditional narrative motifs, such as supernatural enemies, supernatural helpers, magic and marvels, tasks and quests, and common themes (Norton, 1999). Typically, the writers' names have been lost over time, but the stories live over repeated telling; they are passed on from one generation to the next to demonstrate a lesson, moral principle, belief or tradition that a specific folk culture considers extremely significant.

In general, some stories have one or more of the following characteristic features.

Simplicity: Folktales are simple stories of simple individuals. It is easy to understand the language. The definitions are transparent and clear. Either good or evil, strong or weak, rich or poor, wise or stupid are the characters. It is easy to love or hate them, to value or to abhor them. The folk characters are straightforward and easy to understand.

Fantasy, magic and the supernatural: Typically, folk tales contain one or more of these elements. Something very magical occurs in almost every folktale. Trees and beasts talk. Gods fall from the heavens and, in supernatural ways, alter everything. Wizards, witches, fairies, or goblins may perform miracles or cause mischief. Fantasy, sorcery, and supernatural intervention make a good story and appeal to the imagination of the reader in the course of ordinary events.

Customs, traditions and beliefs: Folk tales remind individuals of their ancestral heritage. People are connected to their heritage and embedded in their past through customs, rituals and beliefs conveyed in folktales. And, hence, in the retelling of the stories, these cultural elements are passed on through the generations.

A Moral: Folk stories always contain a moral. In other words, they teach an important lesson about human nature that is clear and convincing. It is the moral lessons they teach that make them live through the centuries. Parents use them to teach their children important lessons that will prepare them to live well with a deeper understanding of their fellow human beings.

Therefore, students may engage in their own cultures by using traditional folk stories in the EFL classroom. They are ready to focus on the beliefs, aspirations, and practices of others with a greater degree of intellectual objectivity by exploring their own cultures, i.e. by examining the values, expectations, traditions, customs, and rituals in which learners unconsciously take part (Straub, 1999).

There are some advantages of teaching culture. Tavares and Cavalcanti (1996) note that teaching culture will improve the knowledge and interest of students about the target culture and their own and allow them to make comparisons between cultures. In line with this, Thanasoulas (2001) notes that cultural teaching should make learners aware of speech acts, connotations, etiquette, acceptable or inappropriate conduct, and give them the opportunity to be a part of the target culture to act out. In addition, as quoted in Thanasoulas (2001), Tomalin and Stempleski (1993) described some objectives of culture teaching as follows: 1) To encourage students to appreciate the fact that all individuals display behaviours that are culturally conditioned; 2) To encourage students to recognize that social factors such as age, gender, social status, and place of residence affect the ways people talk and act; 3) To encourage students to become more conscious of traditional behaviour in the target community in common circumstances; 4) To encourage students to lift their awareness in the target language of the cultural connotations of words and phrases; 5) To encourage students to build the capacity, in term s of supporting evidence, to assess and refine generalizations about the target community; 6) To help students to develop the required skills to locate and organize target culture knowledge; 7) To stimulate the intellectual curiosity of students about the target culture and to foster empathy for its people.

There are a number of Indonesian folktales that can be taught to students. English teachers may use folktales to explain the beliefs, traditions, rituals and principles of people from whom folk tales originate. Moreover, the use of folktales is also very suitable for the incorporation of cultural knowledge and moral values into the EFL Classroom. For example, Malin Kundang, one of West Sumatra's Indonesian folk tales, contains some cultural knowledge and moral values. Teachers can illustrate the moral lesson of the story of Malin Kundang, for example: we must respect our parents. English teachers may also explain by showing pictures of some west Sumatra cultural knowledge, such as West Sumatra customs to go overseas (merantau), Rumah Gadang as a traditional West Sumatra house, and other west Sumatra tourist objects such as Jam Gadang. Another example is the story of the legend of the Prambanan Temple of Central Java. Through this story, a teacher can discuss the moral lessons of the story, such as "do not force our will on others, respect what others want." In addition, some cultural awareness can also be promoted through the story, such as the Prambanan temple, which is a tourist destination while on vacation in Yogyakarta, is the largest Hindu temple in Indonesia. The teacher may show a video or a picture of the Prambanan temple when explaining the place for students who are not from Yogyakarta. By integrating cultural knowledge, students will improve their understanding of the 
sense of the Indonesian philosophy of unity in diversity. It can also support the Indonesian government program to integrate local content and character building for students into the curriculum 2013 by integrating cultural awareness and moral values.

\subsection{Folktales and Language ASPeCtS}

Many experts agree that literary works such as folktales are ideal for use in language teaching. As cited in Alim (2011), Povey (1972) notes that literature can improve all language skills because it can expand linguistic knowledge by providing evidence of systematic use of vocabulary and complex and precise syntax. Langer (1997) pointed out that literature could open possibility horizons, enabling students to challenge, interpret, interact and explore. Additionally, Taylor (2000) states that folktales match well with communicative strategies that concentrate on teaching language to express meaning. Therefore, in addition to cultural awareness, the use of folktales as teaching media in the EFL classroom can also contribute to enhancing the comprehension of language aspects of learners.

Folktales may allow learners to widen their vocabulary. For most language learners, vocabulary mastery is a common issue. It's almost impossible to ask students to memorize dictionary vocabulary, not just because of their ability, but also because of their motivation. They may not have a great intention of mastering the vocabulary if they are not curious about English learning materials. Therefore, setting a context that encourages the effort of learners to memorize vocabulary will in spire their desire to understand and memorize the meaning of the material terms.

A fascinating subject in a folktale can raise the curiosity of learners to be interested in the text. Understanding the main idea or the subject of a folktale implies that the learners have carried out an exercise of brain storming that trains their mind to have a close relation with the subject matter. Once learners feel the sense of inclusion in the text, they will be very willing to find out the meaning of difficult words.

Enriching the vocabulary of learners is very critical for promoting their success in English. In this case, learners have more flexibility within an appropriate context to perceive the meaning of a certain vocabulary. Later, this comprehension will improve the ability of learners to guess the meaning of a difficult word from its context. Later, teachers can help give the meaning of a certain word from the text to increase the word power of the learners and encourage learners to perform the following tasks, e.g. finding the synonym and the antonym of that word.

Learners may use those terms to create sentences in a more advanced class. This exercise promotes the understanding of the contextual sense of the term by learners as well as provides learners with specific experience or cultural interaction with language. This contextual and cultural awareness will make it easier for learners to appreciate the richness and diversity of the use of language. If it is well controlled, it can draw the interest of learners, and at the same time improve their language control. It is assumed that this approach makes the class more vibrant and engaging.

The use of folktales can assist English teachers to explain grammar as one of the aspects of language. One language 's structure or grammar absolutely differs from the others. In language learning, this grammatical or structural problem also becomes another problem. Learners may feel that 'too complex' is the grammar or structure of the language studied that is different from their native language.

At least the use of literary works will minimize that 'complicated meaning' as they provide the real example of how to apply the grammar or structure rule in sentences. Take the teaching of preposition as an example. Theoretically, explaining it may lead to confusion for learners. By using literary works, if it can be seen how prepositions are used in a particular story, preposition and its application can be more detailed and stronger. This method becomes more helpful by providing the real example of using preposition in a phrase and it leaves a clear impression on the mind of the learners.

In teaching other grammatical aspects, such as document, tense, agreement, direct-indirect expression, etc., the same way can also be used. It is widely noted that the inability to teach grammar is due to the dense structure of the theory. In fact, the mastery of grammar theory by learners does not correlate favourably with their ability to apply the theory in a real language context. It is due to the lack of awareness of learners about the roles of the social setting as the context of the sentence. The obvious contribution of literary work to teaching English would be to reduce the ambiguity of the system as well as to offer the true social meaning.

\section{RESULTS AND DISCUSSION}

Teachers should take certain considerations as follows in order to get great benefits by using folktales in the EFL classroom: 
Language skills or aspects: In a syllabus and curriculum, teachers should consider the language skills or aspects that become learning goals. A proper collection of a folktale would be the first influential factor, since a folktale provides a wide variety of potential language skills. It is true that it is not easy to find precisely definite language skills in a folktale, as several language skills can be found in a folktale. In this case, it should be done proportionally to prioritize or highlight the subject of discussion about related items.

The level of learners' comprehension: In using folktale in the EFL classroom, the second question is about the degree of understanding of learners. The reality indicates that learners are more interested in certain items that they have appropriate knowledge of. The level of complexity of a text should, therefore, be considered by teachers. Teachers may use two levels above and two levels below the comprehension level of learners. If the text is too simple for them to compel them to understand the text, teachers can simplify the words in a text.

Cultural content: It is common for a folktale to be rich in cultural material. The presence of this cultural content will give learners double benefits if a teacher will adequately explain the cultural content. Therefore, a teacher can find some details about the folktale that will be demonstrated to the students in the classroom before using such folktales. A teacher can also ask the students to find out about more folktales that will be used in the next meeting by themselves or in groups, so that they can share their information and the teacher may lead the discussion.

Text size: Text size also plays an important role both in improving the motivation of learners and in exploring the 'secret potential' of learners. The time allocation of the class operation should be taken into account when selecting the length of the document. A shorter text may be simpler to use because the time available for the class is more flexible. Another explanation is that it offers more time and opportunities for students to pay more attention to the substance of the text in order to improve their understanding.

\section{CONCLUSION}

Using folktales in the EFL classroom can contribute to developing the cultural knowledge of students, teaching moral values, and improving the vocabulary and grammar knowledge of students. By means of a traditional folktale, teachers can explain the traditions, customs, rituals, or values of a certain region. Since the folktale includes moral values, teachers can use the moral message of the folktale to advise their students. Students need to know the meaning of words in the text to understand a folktale. If they're interested in the material given, they will be inspired to find out the meaning.

\section{REFERENCES}

Alim, C. N. (2011). Teaching Indonesian as a Foreign Language through Folk Tales. Proceeding of conference at the second annual international symposium of foreign language learning. 29-30 November 2011.

Anderson, B. (2006). Imagined communities. London, United Kingdom: Verso Books.

Babalola, E. T. \& Onanuga, P. A. (2012). Atrophization of minority languages: Indigenous folktales to the rescue. International Journal of Linguistics, 4(1), 158-173.

Cigay, D. T. (2010). Preserving our folktales, myths and legends in the digital era. Journal of Storytelling, Self, Society, 6 (1), 19-38.

Cubitt, C. (2006). Folklore and historiography: Oral stories and the writing of Anglo-Saxon history. In E. M. Tyler, \& R. Balzaretti (Eds.), Narrative and history in the Early Medieval West (pp.189224). Turnhout: Brepols Publishers.

Dundes, A. (2007). Worldview in folk narrative. In S. J. Bronner (Ed.), The meaning of folklore: The analytical essays of Alan Dundes (pp.193-195). Logan: Utah State University Press.

Fuhler, C.J., Farris, P.J. \& Hatch, L. (1998). Learning about world cultures through folktales. Social Studies and the Young Learner, 11 (1), 23-25.

Gottschall, J., Martin, J., Quish, H., \& Rea, J. (2004). Sex differences in mate choice criteria are reflected in folktales from around the world and in historical European literature. Evolution and Human Behavior, 25(2), 102-112.

Haase, D. (1993). Response and responsibility in reading Grimms' fairy tales. Haase, Reception, 230249.

Hamilton, M. (2012). Kentucky folktales: Revealing stories, truths, and outright Lies: Lexington, KY: University Press of Kentucky. 
Harun, H., \& Jamaludin, Z. (2013). Folktale conceptual model based on folktale classification system of type, motif, and function. Proceedings of the 4th International Conference on Computing and Informatics. 352-357.

Ismail, I. (2019). The Impact of Interactive Reading Using Local Folktales Stories in Supporting Students' Vocabulary Achievement in Indonesian EFL Learners. Majesty Journal, 1(2), 25-37. https://doi.org/10.33487/majesty.v1i2.119

Langer, J. (1997). Literacy Acquisition through Literature. Journal of Adolescent and Adult Study, 8 (4), $10-18$.

Lwin, S. M. (2009). Revisiting a structural analysis of folktales: A means to an end? The Buckingham Journal of Language and Linguistics, 2(1), 69-80.

Norton, D.E. (1999). Through the eyes of a child: An introduction to children's literature (5th ed.). Columbus, OH: Merrill.

Prasetyo, A. (2016). Folklore in EFL: The Local Wisdom Implementation of Indonesian Curriculum. Journal of ELT Research: The Academic Journal of Studies in English Language Teaching and Learning, 1(2), 194-199. Retrieved from https://journal.uhamka.ac.id/index.php/jer/article/view/61

Prastiwi, Y. (2013). Transmitting local cultural knowledge through English as foreign language (EFL) learning as a means of fostering unity in diversity. Academic journal of interdisciplinary studies, 2 (7), 507-5018.

Ragan, K. (2009). What happened to the heroines in folktales: An analysis by gender of a multicultural sample of published folktales collected from storytellers. Marvels \& Tales, 23(2), 227-247.

Straub, H. (1999). Designing a Cross-Cultural Course. English Forum, 37 (3)

Tavares, R. \& Cavalcanti, I. (1996). Developing Cultural Awareness in EFL Classrooms. English Forum, 34 (3), July-September, 1996.

Taylor, E. K. (2000). Using folktales. Cambridge: Cambridge University Press.

Thanasoulas, D. (2001). The importance of teaching culture in the foreign language classroom. Radical pedagogy. 1-25.

Westland, E. (1993). Cinderella in the classroom: Children's responses to gender roles in fairy-tales. Gender and Education, 5(3), 237-249. 
